\title{
Code-Mixing in Biliterate and Multiliterate Irish Literary Texts
}

\author{
Tina Bennett-Kastor \\ Wichita State University
}

Copyright (c) 2008 by Tina Bennett-Kastor. This text may be archived and redistributed both in electronic form and in hard copy, provided that the author and journal are properly cited and no fee is charged for access.

Abstract. Code-mixing and code-switching are common and well-documented processes in the speech of multilingual persons. Where multilingual persons are also literate in each language, code-mixing is also possible in writing. Despite conservative pressures which tend to deem only one of the languages in a linguistic repertoire the prestige variety, and therefore the primary choice for written expression, multiliterate authors who are able to assume a multiliterate readership may use two or more languages in their texts. Some theories of code-mixing are here summarized, along with a review of code-mixing in spoken Irish. Examination of code-mixing in modern and contemporary Irish literary texts shows that, structurally, written code-mixing is for the most part similar to what is observed in spoken language. Functionally, however, written mixing often has wider aims. Because writing is a planned and conscious form of language, multilingual writers utilize their greater linguistic repertoires strategically by imbuing different languages with different symbolic meanings. A full appreciation of such texts requires an understanding not just of the languages involved, but also of their functions in the cultural environment and the historical, political, and cultural associations with the other languages.

Key words. Multilingual writing, bilingual literacy, bilingual literary texts, written codemixing, code-switching.

Resumen. El cambio de lengua y la mezcla de lengua son procesos comunes y bien documentados en el habla de las personas multilingües. Cuando las personas multilingües son alfabetizadas en múltiples lenguas, es posible que en la escritura encontremos una mezcla de las lenguas. A pesar de las presiones conservativas que tienden a considerar como variedad de prestigio a sólo una de las lenguas en un mismo repertorio lingüístico, y por lo tanto como primera opción de la expresión escrita, los autores alfabetizados en varias lenguas que son capaces de captar la atención de lectores también alfabetizados en varias lenguas pueden utilizar dos o más lenguas en sus textos. Aquí resumidas, encontraréis varias teorías de cambio de lengua, junto con una revisión de la mezcla de lenguas en irlandés oral. Una revisión de la mezcla de lenguas en los textos irlandeses modernos y contemporáneos muestra que, estructuralmente, la mezcla de lengua escrita es, mayoritariamente, similar a lo que se ha observado en la lengua oral. No obstante, funcionalmente, la mezcla escrita a menudo tiene objetivos más amplios. Como la escritura es una forma planeada y consciente del lenguaje, los escritores multilingües utilizan sus mejores repertorios lingüísticos estratégicamente imbuyendo distintas lenguas con distintos significados simbólicos. Para una apreciación cabal de tales textos se precisa no sólo la comprensión de las lenguas involucradas sino también de sus funciones en el contexto cultural, y de sus asociaciones históricas, políticas y culturales con otras lenguas.

Palabras clave. Escritura multilingüe, alfabetismo bilingüe, textos de alfabetismo bilingüe, mezcla de lengua escrita, cambio de lengua.

ISSN 1699-311X 


\section{Introduction}

Abundant research has explored language contact and its manifestations in spoken language, yet much less has focused on phenomena associated with language contact in written texts. Nevertheless, in many parts of the world, multilingual authors have taken advantage of the greater linguistic choices available to them and used them artfully, as it were, to convey layers of meaning which will resonate with their multilingual readers. In situations of language contact, a sizeable portion of the population may be multiliterate - literate in more than one of the languages involved in the contact. It is this type of literacy which is inclined to manifest language mixing of various sorts.

Despite the relative neglect of multiliteracy and specifically of language mixing in written texts, it is by no means a recent phenomenon. Adams et al. (2002) comprises chapters on numerous cases throughout the ancient world of inscriptions in which languages have been mixed to one degree or another, in some cases even languages with different scripts. Constant linguistic and cultural contact in the ancient world produced many cases of code-mixing in written form, from funerary inscriptions and other monuments, on the one hand, to texts by such scholars as Pelagonius (Langslow 2002: 37) and Cicero (Swain 2002: 137-138) on the other hand, as well as in parts of the Bible, e.g., in the Book of Daniel, "mene, mene, tekel, parsin" (5:25, NIV ); the Gospel of Mark, "Talitha koum" (Mk. 5:41, NIV); or the First Letter of Paul to the Corinthians, "Marana tha!" (16:22, NIV).

\section{Structural categories of mixing and switching}

Given the existence of such texts, one must ask in what circumstances and for what purposes written mixing is called into play. Are these similar to what one observes in speech? Pieter Muysken has distinguished cases of lexical borrowing from codemixing, the use of lexical and/or grammatical features from more than one language within the same sentence; and code-switching, the "rapid succession of several languages in a single speech event." (1). Code-mixing and switching may consist of insertion, i.e., placing "material (lexical items or entire constituents) from one language into a structure from the other language"; alternation between different structures; and congruent lexicalization, which places "material from different lexical inventories into a shared grammatical structure” (3). Insertion is akin to spontaneous borrowing; alternation is a "true switch from one language to another, involving both grammar and lexicon"; and congruent lexicalization occurs when the two languages are sufficiently similar in lexicon and/or grammatical structure perhaps even containing homophonous elements - such that the point of switch is ambiguous (Muysken 2000: 5-6).

Adams et al., working with ancient inscriptions, generated their own list of contact phenomena, including some which are parallel to spoken phenomena. These from a continuum of 1) insertion of "ritual words, aphorisms, tags" from L1 to L2 text (7), which is not necessarily indicative of bilingualism any more than an English speaker's use of il va sans dire indicates fluency in French; 2) translation, where two (or more) texts appear in the same location, both conveying the same meaning - as in the Rosetta Stone -, or "alloglottography", where the L1 is used "to represent an utterance in another language (L2) ...in such a way that the original utterance in L2 can be accurately and unambiguously recovered from the document in L1" (Langslow 2002: 44); and 3) diglossia, where the bilingualism of a text reflects a society that is already bilingual, perhaps differentiating between high $(\mathrm{H})$ and low (L) varieties, and unfolds according to functional differentiation, domain, or some other principle.

\section{Functional categories of mixing and switching}

While the diglossic principle is in some ways a functional explanation, what "other principles" might explain an author's conscious use of material from another language? The literature suggests some purposes. The less dominant languages may be written, but without formal recognition or the imprimatur of legitimacy. In these cases, the writer who sneaks nondominant languages into texts - and usually this 
writer is a native speaker of a nondominant language - may be performing an act of subversion that might even be viewed as a kind of treachery. Unlike the conversational discourse of multilinguals, in which languages are invariably encroaching upon one another in various ways, the written word in its conservatism, as symbolic of power and learning, has in history often sought to be "pure" of extra- and interlinguistic effects, an idealized language which is usually not, or not any longer, a truly native dialect. This subversive use may come to be exploited toward various ends, as it was in the Spanish-English codeswitching of Latino and Latina writers to signify their bi-cultural identity (Kraver 1997). Another language can also serve as an assertion of nationalism, particularly where the language in question has had to "go underground", as it were, in the face of hegemony from a colonial tongue; or it may serve to signify the writer's identity as "other" than mainstream and a rejection of the values associated with the dominant language; or in some cases the "other" language may even be a marker of prestige, as in the case of Cicero's use of Greek (Swain 2002: 138), or as it would in contemporary writings in modern languages which include portions of Latin and Greek. Less dominant languages may also be used where the text is largely in the $\mathrm{H}$ language, but particular characteristics associated with the $\mathrm{L}$ varieties allow code-switching to transfer these characteristics to a character, concept, or event depicted in the text. As well, semantic associations with a no longer dominant language may dictate switching, as in the case of the Channel islands of Guernsey and Jersey, where formal and ceremonial functions, such as legal proceedings, required the use of Standard French, for which an English translation then had to be supplied (Price 191). In this case, the function of the code-switching is purely historical in nature.

\section{Multilingualism and Multiliteracy in Ireland}

In Ireland, the sociolinguistic context in which code-switching and mixing may occur is not yet one of an integrated and full bilingualism. Except in specific speech communities, the use of Irish and English tends to be parallel, and despite the potential for robust multiliteracy, publication is still overwhelmingly in English, albeit with Irish (and occasionally other languages) mixed in. Those writers who use literate Irish habitually often must be subsidized to make up for the limited market. On the other hand, where the continuum of multiliteracy ranges from one extreme of speakers who cannot read or write in either language, to a middle position of speakers able to write only in one language but not the other, to a more typical diglossic multiliteracy in which speakers are (supposedly) biliterate, but the languages are functionally differentiated, Ireland is closer to the diglossic end. Thus, failure to write in the L variety (here, in one view, Irish) is a constraint easily broken by innovators. These innovations probably began first in informal contexts, and were then expanded by a minority of writers into formal works.

In the last two decades the renaissance of literature in Irish has reclaimed the older literary tradition, allowing for an examination of 1) whether code-mixing and switching occurs in texts utilizing Irish as the primary code; 2) whether code-mixing and switching occurs in texts using English as the primary code; and 3) what such deliberate weaving of English into Irish text and of Irish into English text represents. Here, we will be examining examples of Irish literary texts which exhibit language mixing, which are written by multilingual authors (i.e., authors literate in two or more languages), and which assume a multilingual audience and are therefore examples of multiliteracy. After briefly examining theories and data pertaining to code-switching and mixing in spoken language, and code-switching in spoken Irish in particular, we will explore the dimensions of mixing in sample texts to determine which structural categories of language interaction are fitting for analysis of literary language, and what functional categories best allow us to understand the authors' purposes in mixing languages.

\section{Code-switching in theory and practice}

The linguistic phenomena of code-switching and code-mixing have been examined from both theoretical and descriptive perspectives 
beginning in the 1960's when Ferguson published his seminal work on diglossia (1959, 1964), noting that "in many speech communities, two or more varieties of the same language are used by some speakers under different conditions" (1964: 429). In this case, the code-switching involves the specialization of different dialects, deemed high $(\mathrm{H})$ - i.e., prestigious - and low (L), for different functions, and thus the codeswitching is what Blom and Gumperz termed "situational" (1972: 424) and is distinct from code-mixing. Ferguson notes that such switching has no doubt existed for millennia although had been seldom mentioned prior to the publication of his work. "Metaphorical" code-switching is also possible. In this case, changes in situation do not elicit the switch, but rather changes in topic, subject-matter, or social event, such as occurs when an exchange of greetings is in the $\mathrm{L}$ variety and is then followed by a business transaction in the $\mathrm{H}$ (Blom and Gumperz 1972: 425).

Code-switching may extend past varieties such as dialects to encompass different languages in speech communities which are bi- or multilingual. If one of the languages is considered prestigious and associated with a literary tradition, the languages are differentiated functionally and the situation is known as "extended diglossia" (Fishman 1980). Viewing the situation in Ireland as a case of such typical functional differentiation is problematic, however, since both English and Irish have enjoyed a literary tradition at various points in history. On the other hand, there are multilingual communities which are not diglossic per se, but code-switch for purely practical or even polite reasons. Salisbury (1962) describes the Siane of New Guinea as people who prize languages and make an effort to learn as many as possible; they use one language or another according to circumstances such as the language of the person to whom they are talking. The Irish might also be viewed as falling into this category. A third explanation is that codeswitching may be compensatory, as when elements of one language substitute for those beyond a person's fluency in the other (cited in Leiwo 2002: 172). This explanation of switching is viewed skeptically by, for example, Muysken (2000), although this author has both personally observed speakers switching languages under such conditions and has done so herself.

Code-switching is thus the shifting of an individual speaker from one varietydialect, language - to another at a distinct "switch-point" which marks the transition from one context to another, as from one type of speech event to another (such as greetings versus business transaction), one type of participant to another (intimate versus superior), or one type of topic to another. Code-mixing, in contrast, is the use of one language in the midst of another within a speech event and even within a sentence, phrase, or word. It is sometimes referred to as "intrasentential switching."As noted above, Muysken describes these kinds of insertions at the word-level as "spontaneous borrowing," which must be distinguished from the kinds of borrowed words and phrases which are considered a part of the lexicon even of most monolingual speakers.

Descriptions of code-mixing abound, although explanations are rarer. Theories have focused on the characteristics of switch-points with the idea, presumably, of predicting potential code-mixes. Muysken summarizes and offers critiques of some of these theories. In their specific detail they go beyond the purpose of the current work, relying as they do on elements of contemporary syntactic theory such as a government and binding framework, but they do illuminate some of the problems which must be treated if a adequate explanation of the principles underlying code-mixing is the be formulated.

An early attempt at developing explanatory principles for code-switching was Shana Poplack's (1980) study of Spanish-English switching by a community of Puerto Ricans. She proposed the notion of linear equivalence: the two languages involved have to have equivalent grammatical word order both before immediately before and immediately after the switch point.

This would seem to preclude certain switch locations in Irish-English mixes since Irish is verb-initial and English subjectinitial, Irish subject and object are adjacent but they are separated in English, and Irish noun phrases are typically in noun-adjective 
order and those of English adjective-noun (but see below). She claimed that codeswitching can be defined as the juxtaposition of sentences or parts of sentences, each of which is internally consistent with its own language.

Among the more recent explanations is The Matrix Language Frame (MLF) theory of Carol Myers-Scotton (1993; also MyersScotton and Jake 1995), which includes sociolinguistic as well as strictly structural factors. She describes code-switching (in many cases, she uses this term to include mixing) as typically being a marked choice, but the members of a speech community have a shared knowledge of the conditions under which the various codes (here, languages) are marked or unmarked in specific situations. Intrasentential switching tends to reflect situational informality and have a positive and unmarked function. Structurally, Myers-Scotton distinguishes between a matrix language (ML) and an embedded language (EL). Code-switching (mixing) follows either the "morphemeorder principle" or the "system morpheme principle." The former maintains that is the ML which dictates the order of words or morphemes; the latter maintains that the "system" morphemes - i.e., function morphemes - come from the matrix language and content morphemes may come from the EL only if they are "congruent" with ML content morphemes, i.e., "having the same status in both languages, taking or assigning the same thematic roles, and having equivalent pragmatic or discourse functions" (Muysken 2000:17). The EL and ML are separated psycholinguistically, however, as "islands."

The MLF model has been criticized for its rigidity of the notion of ML while at the same its unclear definitions of system versus content morphemes and of congruence, and less than full explanation of psycholinguistic factors such as the existence of "compromise strategies" that speakers use to avoid incongruencies between the ML and the EL, although other models have been equally criticized along similar lines" (Muysken 18). In the case of Irish-English switching, the ML and EL are often somewhat interchangeable.
Although not a fully adequate theory, the MLF model shows what a theory of codemixing must take into account. These are the structural constraints - grammatical or lexical features that make insertion or alternation at a given point feasible; the sociolinguistic constraints - the conditions under which, in a given speech community, switching or mixing is marked or unmarked; and the psycholinguistic constraints - the abstract and cognitive representations of morphemes belonging to separate languages as being somehow "congruent" enough to be mutually substituted.

Muysken's development of codeswitching and mixing explanations utilizes the concepts of insertion, alternation, and congruent lexicalization. His category of insertional code-switching includes three properties: the Adjacency Principle that "if in a code-mixed sentence two adjacent elements are drawn from the some language, an analysis is preferred in which at some level of representation (syntax, processing) these elements also form a unit” (2000: 61); that what is switched tends to form a constituent, i.e., "any syntactic unit, either a lexical item (e.g., a noun) or a phrase (e.g., a prepositional phrase)" (61); and finally, switched elements are usually content rather than function words (63), a property compatible with both Poplack and MyersScotton. Alternation is more likely to have occurred when elements from a language A both precede and follow an element from a language B which is not structurally related. Muysken argues that length and complexity also come into play, since as the number of "words the switched element contains" increases, or the more complex the switched fragment is, the more likely it is to an alternation rather than an insertion." Furthermore, the "activation of a matrix language" probably "decreases as the number of words in the intrusive language is larger" (97). As for congruent lexicalization, it is more likely to occur in speech communities where either " $t]$ here is an overabundance of homophonous words...that serve as bridges or triggers for the code- mix" or else "[t]here is a general structural equivalence... without there necessarily being any lexical correspondence” (123). The greater distance 
or dissimilarity there is between one language and another, the less likely congruent lexicalization is to occur, and in the case of Irish and English it would seem to be dispreferred. For Muysken generally, properties of various types of mixing and switching are more appropriately viewed as strong tendencies than as inviolable principles.

\section{Code-switching in spoken Irish}

Despite the long history of language contact and bilingualism in Ireland, empirical descriptions of Irish-English (or EnglishIrish) code-switching and mixing are almost nonexistent. Stenson (1990) published what she believed to be the first study of IrishEnglish code-switching, in this case for the purpose of both presenting examples and for testing the various constraints of codeswitching that have been proposed. She maintained that linguistic theory, to be adequate, must be able to account for codeswitching because among bilingual communities code-switching is "an integral part of the linguistic competence the theories are intended to describe" (168). Stenson claims that "code-switching by Irish speakers in uni-directional. While ample evidence exists of English within Irish discourse, in her data Irish is never inserted into English discourse (169). She notes, however, that this may have been true because the people studied only spoke English to those who could not speak Irish anyway (194, note 1). Because the Irish literary texts used for the present study include both predominately English texts and predominately Irish texts, bi-directional mixing is possible.

As virtually the only study of IrishEnglish code-switching, Stenson's findings, where relevant, will here be summarized in some detail. In her data, switches between sentences seldom occurred. The few exceptions were cases when an Irish speaker was reporting speech in English and when the addressee was changed from one sentence to another (169). These examples may be alternations between the languages. Intrasentential switching is the primary type observed, and it usually involves single lexical items which by phonological criteria do not appear to be borrowings into Irish. Nouns are especially frequently inserted (170). When adjectives are inserted, they are usually in predicative position, e.g., "Tá mé ag fáil jealous", although some show adjectives within a noun phrase ("Tá carr light green aige"). In the examples cited, the English adjective follows the noun as is consistent with Irish syntax. Interestingly, the exceptions to this are English expletives used adjectivally, i.e., “fuckin'," “friggin'," or "bloody” which precede the noun (171-2). Similarly, there are adverbial switches in initial, medial, and final position (e.g., "Just cuir ar an mbord é") (172), and, somewhat less frequently, prepositional phrases (PPs) with adverbial function ("Ní féidir é a chur as an tír on any account”) (173). Rarest are verbs, although it is particularly difficult to unambiguously identify as switches English verbs that are morphologically assimilated and given the suffix -áil. Only a few examples involved an verb that was clearly English, complete with English tense or participial suffixes (173-4). Finally, English phrases often provided introductory phrases to Irish complements, as in "You bet go bhfuil sé te" (174).

The Irish data obey some of the various proposed constraints Stenson examined but not others. For instance, if the English verbs with Irish morphological suffixes are counted as borrowings rather than as switches, they are consistent with various proposed constraints, but otherwise not. Adjective data also contradict both constraints against postnominal adjectives and claims that the language of the adjective determines its placement. Stenson found just one example of an English adjective preceding an Irish noun; in every other case the syntax of Irish determined the placement of the adjective. Similarly, while Pfaff (1979), in a study of Spanish-English data, found the switching of whole PPs to be rare, Stenson's data showed that locative PPs in English were rare but that temporal and figurative PPs were fairly commonly switched. Finally, the Irish speakers tended not to switch for conjunctions, but "complementizers always appear in the language of the clause they introduce" Stenson (177-9). She goes on to propose solutions within a government-binding context to the unaccounted-for Irish-English switches. These are not directly relevant to the purposes of the current work, but 
Stenson does offer the suggestion that an adequate theory of code-switching - in fact, an adequate linguistic theory in general must utilize a broader range of linguistic data than that from the Germanic and Romance languages that dominated many earlier attempts to explain code-switching.

\section{The texts}

The texts examined here which reflect the mixing of languages are only a small subset of those which might have been cited (cf. Bennett-Kastor, in submission, which includes others). The methodology by which the textual data were selected was admittedly unorthodox insofar as there is no single repository of bi- or multilingual writing in the way in which there are clearly delineated communities of bilingual speakers, and so the author had to rely on scholars who had wide-familiarity with Irish literary works in either Irish or English. During a visit to the Linguistics Institute of Ireland (ITE) in Dublin over the course of several days, the author explained the sort of literature which she wished to examine, asked if anyone knew of any examples of it, and then was ably assisted by two staff members in particular who immediately knew of such texts and supplied several of them. In many cases the texts were held in the Institute's library; in other cases a staff member owned a text in a private collection and provided photocopies. In some cases the text itself was not available, but citations of mixedlanguage passages appeared in secondary sources. Subsequent to the research at ITE, the author came across several other examples, first-hand or in secondary sources. The texts collected dated from the $17^{\text {th }}$ through the $20^{\text {th }}$ centuries, and included poetry, drama, fiction, nonfiction, and in one case diary entries. Most were in Irish with English mixing; fewer were clearly English with Irish mixing (see below). Of these, the data analyzed here are restricted to works from the late $20^{\text {th }}$ century and the first few years of the $21^{\text {st }}$, works which would have been produced in a sociolinguistic context more conducive to and familiar with spoken code-mixing and switching than in earlier times. Although it must be assumed that the texts sampled do not form the entire collection of works exhibiting language mixing, there is nevertheless no a priori reason to assume they are not a representative sample of biand multiliterate literary texts in Ireland. In fact, for each example provided, there were many others of the same type.

Included here are works of fiction in English: Frank McCourt's Teacher Man (an Irish-American offering) from the $21^{\text {st }}$ century, and Maeve Binchy's $20^{\text {th }}$ century Firefly Summer; poetry in Irish: Cathal ó Searcaigh's "Do Jack Kerouac" ("For Jack Kerouac") and "Cainteoir Dúchais" ("Native Speaker"), and Nuala ni Dhomnaill's “An Crann” (“The Tree”), all late $20^{\text {th }}$ century; drama in English: Brian Friel's 1980 Translations; and also in Irish: Antoine ó Flatharta's 1990 Grásta i Meiriceá.

Lexical borrowing. As with most dialects of English created via contact, HibernoEnglish contains a great deal of lexical borrowing. Irish words, as well as Norman French and Early Modern English expressions, therefore have made their way into work by Irish authors writing in English. As such, the mixing may be in some cases simply a dialectal feature. As Muysken and Stenson have both observed, it is necessary theoretically but also difficult to distinguish loanwords which have been fully incorporated into a language from "spontaneous borrowings," i.e., insertions. However, if a fluent writer of Standard British English uses either Irish or HibernoEnglish loanwords for an audience that may be assumed to know neither, the effect is perhaps the same as a true insertion. Nevertheless, these examples have been identified as borrowings (loanwords) rather than insertions on the grounds that they appear in Dolan's Dictionary of HibernoEnglish (1999).

In Frank McCourt's 2005 memoir Teacher Man, although published by an American house, we find such examples as, "I'm hardly old, said my mother, so none of your plamas" (34) [Ir. plámás, "flattery"], and "Arrah, jaysus, you're not a yank at all" (158) (< Ir. dhera [interj.], [Dolan 1999: 12], or arú [interj.], [ó Dónaill 1977: 62]). These examples represent the insertion of a noun within a noun phrase and of an interjection. In Stenson's data of English 
mixed into Irish, nouns are inserted into noun phrases, although she provides no examples of the insertion of an interjection - unless it may be considered an adverbial of sorts. Functionally, in each case the borrowing is in the speech of an Irish person in a book full of Americans and Irish-Americans. Maeve Binchy's Firefly Summer (1988) contains a metalinguistic example: "It's the poor French children I worry about...she has taught them all to say pogue mahone [= póg mo thóin, "kiss my arse"]. They think it's Irish for good morning" (544-5, noted in Dolan 1999: 202). Here, the structural properties of the borrowing match those of Stenson's English-in-Irish examples where the matrix predicate is in one language and the embedded complement in the other. Functionally, the borrowing (or possibly insertion, although the spelling is Anglicized) serves - aside from injecting humor - to demarcate the cultural and linguistic division between characters. In fact, many of the contemporary Irish writers publishing in English insert Irish (or possibly Hiberno-English) to indicate that the setting or characters or in some cases theme of a work is specifically associated with Irish, as opposed to English or American, culture. It is something like the equivalent of providing "local color" in fictional work with a specific regional setting.

Insertion (Code-mixing). One of the bestknown contemporary poets writing in Irish, Cathal ó Searcaigh, also uses code mixing (and code-switching; see below), sometimes extensively. Possibly his most widely known poem is "Cainteoir Dúchais" ("Native Speaker"), turns on its head the notion his own generation held in their youth that Irish and Irish speakers were conservative, rural, and square and English was associated with liberality, urbanity, and hipness. At the same time, the poem, illustrates the uneasiness with which a native speaker must swim in a sea of dominant and capitalistic Englishness. In the first stanza,

Bhí sé flat-out, a duirt sé...

Rinne sé an t'árasán a hoovereáil, na boscaí bruscair a jeyes-fluideáil, an loo a harpickeáil, an bath a vimeáil.
Ansin rinne sé an t-urlár a flasháil Na fuinneoga a windoleneáil,

Agus na leapacha a eau-de-cologneáil

(Ó Searcaigh 1997: 134), the narrator used the English slang to say he was "flat-out" (tired) - an adjectival insertion used predicatively and thus consistent with Stenson's data -, and throughout each of the following lines are inserted a host of English-made cleaning products. These appear as verbs derived from the English brand name with the Irish verbal noun suffix; structurally, these insertions are not unlike those which occur in spoken language when a borrowed word becomes fully integrated into the borrowing lexicon, and Stenson noted that these do not violate constraints on insertion as long as they are counted as loanwords--although these verbs are not clearly integrated into the lexicon of the average Irish speaker. Functionally, however, they are intended to mirror the infiltration of English commercialism into Irishness (Tochigi 142).

In the second stanza, although the narrator is tired - here the word is the adjective "shagáilte" and again used predicatively nevertheless

rachadh sé amach a chruiseáil;

b'fhéidir, a dúirt sé, go mbuailfeadh sé

le boc inteacht

a mbeadh Gaeilge aige (134).

He intends to go out "cruising," perhaps to meet a "buck" or "playboy" who "would have Irish". Again, while the insertions are not structurally anomalous, they reveal functionally an additional layer of meaning, for the narrator is gay and looking for a tryst with another Irish speaker. Now the ambiguity of shagáilte emerges, because 'shag' is the root of both the British slang term "shagged-out" (tired) and the HibernoEnglish word for having intercourse (Dolan 1999: 236). Code-mixing here thus marks the narrator as not only an outsider to the urban English world, but as sexually outside the mainstream. In the English translation, the last lines read: "he might run into someone/ with a cúpla focal” (135), i.e., "a few words", a common Irish phrase used sometimes over-modestly - by those who know some Irish (Tochigi 2000: 142).

An additional functional layer that is often associated with diglossic speech com- 
munities is the result of a "colonialist construct" whereby those in positions of political superiority speak the language of the colonists, and those occupying the lower realms of the social strata speak the language of the colonized. Such a construct was built of an extensive collocation of dichotomies which are invoked whenever the two languages meet within the same text. Alastair Pennycook (1998) sets up the dichotomy as that between the "Other" (colonized) and the "Self" (colonists) alluded to in the Introduction. The Other is "named" and "derogated" by the Self (30), literally, as it often involves replacing the native names of places, people, and things with the colonists' name. The Self is enlightened, modern, civilized, Christian (in Ireland's case, Protestant), rational, male, and speaking a European language. The Other is savage, primitive, backward, heathen (or Catholic), irrational, female, and speaking some "other" language. The British felt it their "moral duty" to "enlighten" the other (48). And while Irish is just as European a language as English, the power of the colonial construct was such that the native Irish were persuaded that they were not European, not modern, not civilized, and not worthy. Thus did many, especially in the North, voluntarily give up their language in exchange for "success, culture, and literacy", thereby strengthening the association of Irish "with poverty, backwardness, and lack of opportunity" (Zwickl 2002: 21). It is this construct which allows ó Searcaigh to associate homosexuality with the "other" language (Irish) and English with modern civilization and thereby utilize metaphorical rather than strictly situational codeswitching/mixing.

Alternation (code-switching). Irish can also be seen to alternate with English at the larger structural levels of one or more sentences, indicating code-switching, which may also functionally invoke the colonial dichotomies as well. In the contemporary poem, "An Crann" (“The Tree”) by Nuala Ní Dhomhnaill, a fairy woman cuts down a tree, infuriating the husband of the woman who narrates the poem. The fairy comes "le ('with a') Black \& Decker", and later asks the narrator what her husband had said about the cut tree. When told, the fairy woman replied,

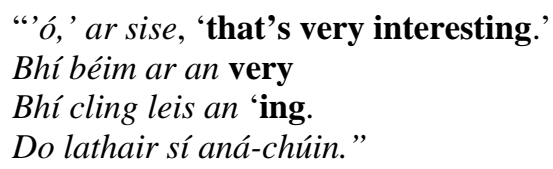

Structurally, this example can be viewed as consisting of either insertion or alternation, or of a combination of both. "That's very interesting" is a complete clause which could be similar to the Binchy example of the "pogue mahone" insertion; however, in this case it may be viewed as an alternation since it represents a switch between speakers - the poet versus the fairy. Again, it is not unusual, as compared to spoken code-switching, for the point of switch to represent different speakers, although one must wonder why a fairy woman is speaking in English. Certainly there are phonological considerations: the "ring from the -ing" perhaps evoking the sound of the chain-saw. This example may be relevant to the issue of matrix versus embedded language, which can be a problematic distinction for the situations such as the one in Ireland where both languages have a literary tradition and both are used in published works. The matrix language of the poem can be said to be Irish, insofar as most of it is in Irish, and the function or "system" morphemes are in Irish; in this case, then, English may represent the other-worldliness of the speaker, since fairies come from another realm of existence but are also creatures to be feared.

Ó Searcaigh, too, uses code-switching or alternation in addition to insertion. His poem "Do Jack Kerouac" ("For Jack Kerouac") describes his fascination with and dreams about the Beat generation (Bhí mé hookailte ort - "I was hooked on you") which began in 1973. He writes of heading out on the highways of America:

“'Hey, man, you gotta stay high,' a

déarfainn le mo chara agus muid ag

Freakáil trí California....” (1983: 188) 
"Hey man, you gotta stay high", I will say to my friend, and we freaking through California." Throughout the poem, both insertions and alternations are compatible with what Stenson observed structurally among Irish speakers. They insertions and alternations exhibit identification, even infatuation, with an artist and a movement which were decidedly young, American, and embodied in American English. Playfully alliterative mixes and switches evoke the tone and the particulars of the era: "booze, bop, agus Búdachas" ("Buddhism"); "marijuana agus misteachas i Meicsico" ("marijuana and mysticism in Mexico"). But the journey "on the road" eventually leads back to "seanaoise is na scoilteacha" ("old age and rheumatism"), and the poet's parting words are "Is ansin, goddammit, a Jack, beidh muid beirt ag síolshiúl sa tsíoraíocht”, "And then, goddammit Jack, we'll both be hitchhiking into eternity" (190, my translation). Again, the matrix language may be said to be Irish: Irish represents a majority of the words in the poem, most of the functional morphemes are Irish, and ó Searcaigh claims he writes in Irish and not in English. Yet some fairly large structural elements appear in English, and the mixing of the two languages within the cohesive alliterative phrases suggests that the author is freely alternating between two languages which, in the context, are equally activated.

A third example, one that is quite clearly intersentential code-switching, comes from ó Flatharta’s play Grásta i Meiricea (1990), the theme of which is the relationship between the worlds of Ireland and America - and of the Irish and English languages for two illegal immigrants from Ireland who are making a pilgrimage to Elvis Presley's former estate, Graceland, in Nashville, TN. One of the characters, Finnbarr, is penning a postcard back home:

Ní creifidh said go deo é nuair a fheichfidh said na postcards seo. (Ag scriobh go mall) 'Howdy Partner. I'm sitting in a bar in Nashville Tennessee'...cé mead ' $e$ ' I Tennessee?...caithfidh mé isteach ceann extra just in case... 'The weather is very hot. I have to go, Dolly Parton is looking for me. Wish you were here.'

(Ó Flatharta 1990: 43, cited in Murphy 2006:2)
This example contains both switching and mixing. All the stage directions, as well as the commentary of Finnbarr to the other character, Seán, are in Irish, with the words of the postcards in English. These alternations are based on the addressee - the actors and directors in the case of stage directions and the other (Irish-speaking) character in the case of the commentary; but (curiously) the words to the family at home in the Gaeltacht are in English. This is a clear type of situational code-switching; the function of the English directed to an Irish audience symbolizes Finnbarr's rather more "eager and ambitious," in Murphy's words (2006:1), approach to America, in contrast to Seán's more guarded attitude. Finnbarr shows off his cúpla focal English, as it were, risking "linguistic and cultural jet-lag once the card returns to its gullible Irish reader" (2).

On the other hand, the English of "extra just in case" is peculiar. Although the English adjective follows the noun, as dictated by Irish word-order, the English continues into the next intrasentential constituent, in a manner not attested to in Stenson's data. Muysken categorizes such a case where a sentence begins with language A then ends with language $B$ as an alternation and presents a similar example which he explains by the earlier use of $B$ acting as a trigger for the latter. Given the "pre-fabricated" nature of Finnbarr's English, however, one would not think his bilingualism to be sufficiently developed to produce alternation. Regardless of this single example of an unlikely alternation, Murphy claims that Finnbarr and Seán's code-switching in the play "literally and figuratively presents their own transience." It is thus a metaphorical use of switching.

Congruent lexicalization. For congruent lexicalization to occur, similarity of grammatical structure or lexicon is required. Irish grammatical structure is considerably different from that of English, although there are situations in which words and phrases overlap, in part because a certain amount of English consists of loan translations from Irish. More common in Irish literature is a metaphorical congruency in which English-speaking characters are assumed to be saying the same thing, but 
speaking in Irish. This is roughly equivalent to Langslow's “alloglottography" - the use of an L1 to represent an utterance in L2. The finest example of this metaphorical congruency is in Brian Friel's play Translations, a play thematically concerned with the usurpation of the right to name one's own world.

Cartographers from the British army come to the little town of Ballybeag ("little town") to make a new ordinance survey. They have hired as a translator Owen, the emigrant son of the local school teacher ("Owen Mor") who had left to seek his fortune in the (English-speaking) city. Owen and the British captain arrive at a hedge-school run by Owen Mor and his other son, the crippled Manus, which is populated by a handful of students, one of whom is mute. The Irish are proud of their linguistic and literary traditions, which encompass not only Irish, but also Latin and Greek. The British, with their pitiable monolingualism, are therefore deemed inferior, but it is they who have come to rework the landscape into pronounceable English, and in some cases even to change the name, and hence the meaning, of a place-name. At one point, Captain Yolland asks Owen, whom he calls by the wrong name of "Roland", what a certain place is called. Owen replies that it is called "Bun na Abhann", meaning "the bottom (or mouth) of the river". The British decide it would be much more conveniently rendered as "Burnfoot", and Owen, as one who sees the future of Ireland to be English, assents to this obliteration of identity.

In the course of the play, Maire Chatach ("Curly Mary") falls in love with a young soldier, George. They proclaim their love to one another in a scene in which Maire repeats the few irrelevant English words she has learned, without fully understanding their meaning, and George responds with his irrelevant handful of Irish. But for the most part, the medium of the scene is English. Yet the audience understands that Maire is not an English speaker at all, and hence accepts that her stage English is, in fact, the Irish language. The genius of Friel's irony is its representation of the reality that most Irish people can only avow their deepest or most passionate convictions in what may be now a native tongue, but not necessarily a mother tongue (Palmer 2001:

1).

\section{Conclusion}

It is a truism that language communicates a wide range of functions within the constraints of its structure. Multilingual persons therefore have at their disposal a greater repertoire of structural potential for the expression of meaning. A fully adequate account of linguistic knowledge must be inclusive of cross-language phenomena and be able to explain the structural characteristics of code-mixing and codeswitching, including the types of sociolinguistic knowledge which multilingual speakers tacitly command. Code-switching, as noted by Myers-Scotton, is on the surface a marked choice, but most conversational language is relatively unplanned, and its intrasentential switching is associated with situational informality in which the switching has an unmarked and positive function even if its semantic and cultural dimensions are also operating below the level of conscious awareness.

Written language, however, is relatively planned, and the careful writer has more time to be aware of dimensions of meaning that lie beneath the surface. In the case of writers who make art with language, while the structure may for the most part be consistent with spoken switching, it is nevertheless a marked choice given that it is in the written and public medium. Multiliterate texts are constructed deliberately so that switch points or other points of linguistic contact within the text often signal additional, metaphorical levels of meaning which are coherent with the theme and/or other aspects of the work. To succeed in delivering these levels of meaning, the multiliterate writer must depend upon readers whose literacies overlap with those of the writer.

The implications for the development of a literary aesthetic in a multilingual society are that it is not enough to recognize that a written work exhibits two or more languages and to understand the meanings of the words in each language. To fully appreciate the aesthetic within the work, the writer and reader both must comprehend the complex political, historical, social, and 
cultural dimensions of the writer's choice of language. As Ireland moves toward an increasingly integrated and full bilingualism, the potential for increased language interaction within literary works will grow. Literary theory, interpretation, and the teaching of literary analysis must keep up with the realization of this potential. As summed up by Palmer, language plays such various roles "as medium of negotiation, as subject of interdictions, as badge of identity, as index of civility, as symbol of otherness, as bearer of ideology, as words in the mouth of a preacher, as battlecry, as lines tumbling off ... printing presses, as ... death-warrant" (2001: 8). The multiliterate writer calls out to the reader in what Joyce described in Ulysses as "that other wor[l]d", and depends on the reader both to hear these echoes, and to understand them.

\section{Works Cited}

Adams, J. N., Janse, Mark., and Swain, Simon (eds.). 2002. Bilingualism in Ancient Society. Language Contact and the Written Text. Oxford: Oxford UP.

Blom, Jan-Petter and Gumperz, John. 1972. "Social Meaning in Linguistic Structures: Code-Switching in Norway”. Directions in Sociolinguistics. The Ethnography of Communication. Eds. J. Gumperz and D. Hymes. New York: Holt, Rinehart, and Winston, Inc., 407-434.

Dolan, Terence P. 1999. A Dictionary of Hiberno-English. Dublin: Gill \& Macmillan.

Ferguson, Charles. 1959. "Diglossia”. Word 15: 325-40. . Rpt. In Language in Culture and Society. Ed. Dell Hymes. 1964. New York: Harper \& Row, 429-437.

Fewster, Penelope. 2002. "Bilingualism in Roman Egypt”. In Bilingualism in Ancient Society. 220-245.

Fishman, Joshua. 1980. "Prefatory Notes”. Languages in Contact and Conflict XI. Ed. P. H. Nelde. Wiesbaden: Steiner. Cited in Wardhaugh, Ronald. 2002. An Introduction to Sociolinguistics. $4^{\text {th }}$ edition. Oxford: Basil Blackwell. 97.

Friel, Brian. 1980 Translations. London: Faber \& Faber.

Kraver, Jeraldine R. 1997. "Revolution through Poetic Language: Bilingualism in Latina Poetry from 'La Frontera””. LIT: Literature, Interpretation, Theory 8 (2). 193-207.

Langslow, D. R. 2002. “Approaches to Bilingualism in Corpus Languages”. In Bilingualism in Ancient Society. 23-51.

Leiwo, Martti. 2002. "From Contact to Mixture: Bilingual Inscriptions from Italy.” In Bilingualism in Ancient Society. 168-194.

Murphy, John L. 2006. “Antoine ó Flatharta’s Elviad: from Grásta i Meiriceá to Grace in America.” Estudios Irlandeses 1. 1-14. www.estudiosirlandeses.org

Muysken, Pieter. 2000. Bilingual Speech. A Typology of Code-mixing. Cambridge: Cambridge UP.

Myers-Scotton, Carol. 1993. Duelling Languages: Grammatical Structure in Code-Switching. Oxford: Clarendon.

Ó Dónaill, Niall. 1977. Foclóir Gaeilge-Béarla. Dublin: An Gúm.

Ó Searcaigh, Cathal. 1997. “Cainteoir Ducháis”. Out in the Open. Ed. G. Fitzmaurice. Indreabhán, Conamara: Cló Iar-Chonnachta. 134-135.

1983. “Do Jack Kerouac”. Homecoming/An Bealach ‘na Baile Ed. Gabriel Fitzmaurice. Indreabhán, Conamara: Cló Iar-Chonnachta. 188-191.

Palmer, Patricia. 2001. Language and Conquest in Early Modern Ireland. Cambridge: Cambridge UP.

Pfaff, Carol.1979. "Constraints on Language Mixing: Intrasentential Code-Switching and Borrowing in Spanish/English.” Language 55. 291-318.

Poplack, Shana. 1980. "Sometimes I'll Start a Sentence in English Y TERMINO EN ESPAÑOL.” Linguistics 18. 581-618.

Price, Glanville. 2000. "French in the Channel Islands”. Language in Britain and Ireland. Ed. Glanville Price. Oxford: Basil Blackwell. 187-196.

Salisbury, R. F. 1962. "Notes on Bilingualism and Linguistic Change in New Guinea”. Anthropological Linguistics 4 (7). 1-13. Cited in Wardhaugh, Ronald. 2002. An Introduction to Sociolinguistics. $4^{\text {th }}$ edition. Oxford: Basil Blackwell. 96-97.

Stenson, Nancy. 1990. "Phrase Structure Congruence, Government, and Irish-English Code-Switching.” 
The Syntax and Semantics of the Modern Celtic Languages. Ed. Randall Hendrick. Syntax and Semantics Vol. 23. San Diego: Academic Press. 167-197.

Swain, Simon. 2002. "Bilingualism in Cicero? The evidence of Code-Switching”. In Bilingualism in Ancient Society. 28-167.

Tochigi, Nobuaki. 2000. "Cathal ó Searcaigh and Aspects of Translation. Éire-Ireland. XXXV (1-2).139149.

Trotter, D.A. 2000. “Anglo-Norman”. Language in Britain and Ireland. Ed. Glanville Price. Oxford: Basil Blackwell. 197-206.

Welch, Robert. 2003. "Faultlines, Limits, Transgressions: A Theme-Cluster in Late Twentieth- Century Irish Poetry”. Éire-Ireland XXXVIII (1-2). 161-180.

Zwickl, Simone. 2002. "Introduction". Language Attitudes, Ethnic Identity and Dialect Use Across the Northern Ireland Border: Armagh and Monaghan. Eds. J. M. Kirk and Donal P. Ó Baoill, Donal. Belfast Studies in Language, Culture and Politics 5. Belfast: Queens UP. XV-xviii. 